DOI 10.38129/ Ann.Yur.Ist.2019.3.3.4.27

УДК 340.115.5(340.115.4: 340.115.6):340.152

\title{
ЕКОНОМІКА І ПРАВО В ДАВНЬОМУ ЄГИПТІ: ВСТУП ДО ПРОБЛЕМАТИКИ
}

\author{
ОЛЕКСАНДР БЕЛОВ (Вінниця, Україна)*
}

V-IV тисячоліття до н.е. - один із найважливіших часів в історії права.

Це - період появи перших юридично повноцінних держав.

Цими першими державами були Древній Єгипет та Шумер.

Древній Єгипет, безумовно, був однією 3 найбільш розвинених $\mathrm{i}$ прогресивних держав давнього світу.

Початок давньоєгипетської цивілізації прийнято відраховувати 3 епохи пізнього палеоліту (VI тисячоліття до н.е.). У цей період у Північній Африці відбувалися кліматичні зміни. Вологі вітри послабшали, настала посуха. Саванна поступово перетворювалася на пустелю. Придатні для життя людей території звужувалися, змушуючи племена, які мешкали на них, рухатися слідом за зникаючими оазисами, ближче до долин Нілу.

Природні умови (насамперед, родюча земля, яка щорічно вдобрювалася розливами Нілу) сприяли переходу до осілого способу життя із заняттям землеробством. В археологічних рештках цієї доби знаходять запаси ячменю та пшениці, а також прості знаряддя: дерев'яні серпи 3 кременевими зубцями, кам'яні зернотерки. Крім землеробства, осіле населення нільських долин епохи пізнього палеоліту займалося скотарством (про що свідчать знахідки численних кісток овець, биків та свиней), а також мисливством, рибальством та збиральництвом. У цей період люди не мали можливості втручатися у природні процеси, і змушені були пристосовуватися до наявних умов.

3 початком енеоліту (V-VI тисячоліття до н.е.) пов'язані перші спроби людей керувати розливами Нілу. Метою цих первісних інженерних зусиль було штучно регулювати час стояння води на полях (для того, щоб керувати ступенем насиченості грунту вологою), а також затримати на полях максимальну кількість поживного мулу. Для цього зводили дамби, греблі, укріплювали береги, будували відвідні канали для води, що дозволяло регулювати рівень вологи на полях. Таким чином, у IV тисячолітті до н.е. в Сгипті була створена басейнова система зрошення, яка активно вдосконалювалася протягом тисячоліття, і збереглася аж до XX 
століття. Така система не давала можливості одержувати кілька врожаїв на рік (це обмеження задавалося водним режимом Нілу, води якого стояли на полях 3 весни до пізньої осені; посів починався у листопаді, а врожай збирали навесні), однак, забезпечували високі й стабільні врожаї. Надзвичайна родючість єгипетських грунтів зумовлена постійним відновленням поживних речовин за рахунок щорічних розливів Нілу; цей природний процес підтримував високу врожайність протягом тисячоліть, не потребуючи сівозмін та додаткового внесення добрив.

Утім, створення іригаційної системи в долині Нілу зовсім не було легкою справою. Навпаки, побудова навіть невеличкої локальної системи дамб, гребель і каналів вимагала колосальних зусиль усіх людей, що мешкали на цій території. Це змушувало окремі племена об'єднуватися у сусідські земельні общини навколо іригаційного господарства. У цих умовах владні еліти (вожді й жерці), що керували та контролювали це іригаційне господарство, отримували не лише силові, а й економічні важелі керування спільнотою. Це прискорило процес майнового розшарування та утворення специфічних спільнот (номів), яким були притаманні як риси земельної общини, так і протодержавного утворення.

Кожен ном гуртувався навколо локальної іригаційної системи; територія зрошення фактично була й територією ному. Ном мав свій уряд (правителя і його наближених), жерців, які відправляли культи місцевому божеству, та воїнів. Таких номів у додинастичний період нараховувалося близько сорока; у Верхньому Сгипті кожен ном безпосередньо межував 3 двома іншими (південним і північним), у Нижньому Сгипті природними кордонами між номами були болота.

Взаємини між номами не були мирними. До нас дійшли сланцеві таблички з малюнками, на яких зображені криваві битви, низки полонених, відбиті череди худоби. 3 часом більш слабкі і маленькі номи були поглинені великими і сильними. Виникали великі об'єднання номів, на чолі яких ставав правитель найсильнішого нома. Процес об'єднання номів тривав майже дві тисячі років, i завершився у другій половині IV тисячоліття до н.е. об'єднанням північних та південних номів у Верхнє та Нижнє царства, які згодом об'єднаються в єдину Єгипетську державу (ТаКемет).

Об'єднання номів було надзвичайно прогресивним кроком. Іригаційні системи окремих номів складалися з невеличких, не пов' язаних одна 3 одною зрошувальних систем. Їх об'єднання дозволило створити єдину досконалу іригаційну систему, реалізовувати масштабні проекти будівництва каналів, гребель, дамб, забезпечувати постійний догляд, 
ремонт та обслуговування зрошувальних систем, ефективно боротися із заболочуванням (а болота не лише заважали землеробству, а й були постійним розсадником небезпечних інфекцій, давали притулок хижим тваринам, отруйним зміям, крокодилам).

Виникнення єдиної давньоєгипетської держави стимулювалося також специфічними природними умовами, що спрямовували розвиток економіки у певне русло. Вузька долина Верхнього Єгипту забезпечувала ідеальні умови для землеробства, і практично вся земля тут була зайнята під посіви. Натомість, просторі пасовиська на місці осушених болот Нижнього Єгипту створювали чудові умови для випасного скотарства. У певний час худобу з Верхнього Єгипту переганяли до Нижнього, на пасовиська; згодом Нижній Єгипет став центром єгипетського скотарства. Крім скотарства, долини Нижнього Єгипту використовувалися для садівництва і виноградарства.

Процес формування єдиної Єгипетської держави тривав до кінця IV тисячоліття до н.е. Головним досягненням так званого додинастичного періоду було закладення економічних та політичних підвалин майбутньої давньоєгипетської держави. Єдина іригаційна система, що охоплювала всю територію долин Нілу, давала можливість одержувати стабільні значні врожаї, забезпечувати ефективне садівництво, виноградарство, скотарство, що закладало основи економічної могутності держави. Функціонування такої складної системи вимагало значної централізації влади, ефективного управління, що сприяло становленню і зміцненню єдиновладдя в Єгипті. До кінця додинастичної епохи також належить виникнення єгипетської писемності, що забезпечило ефективну передачу знань, накопичення досвіду, розвиток науки і культури.

Традиційно історію Давнього Єгипту поділяють на Древнє, Середнє та Нове царства, кожне 3 яких включає по десять династій. Цей поділ, введений єгипетським жерцем Манефоном невдовзі після походів Олександра Македонського, є умовним, однак, досі зберігається у описах історії Давнього Єгипту; до нього лише внесено деякі зміни: перші дві династії виділені у Раннє царство, а останні дві, починаючи з XXI-ї - у Пізнє царство.

Ранне царство, що охоплюе період 3120-2650 рокі८ до н.е., відноситься до часів правління фараонів I та II династій, вихідців з нома Тиніса (Верхній Єгипет). Засновником I династії вважається Менес, хоча знайдена палетка 3 символічним описом перемоги царя Нармера над мешканцями Нижнього Єгипту, свідчить про панування його над усією територією Верхнього та Нижнього Єгипту у додинастичний період. 
Раннє царство - епоха енеоліту. Знаряддя (сокири, ножі, вила, мотики, гарпуни, риболовні гачки, а також чаші та судини) виготовлялося 3 міді. Поряд 3 міддю широко використовувалися кам'яні (кременеві) знаряддя, а також дерев'яні та кістяні інструменти. Навіть 3 такими примітивними інструментами іригаційна система землеробства давала можливість одержувати високі врожаї, а відтак - i додатковий продукт. Останній ставав предметом привласнення владної верхівки, поглиблюючи майнову нерівність і сприяючи утворенню станів.

Швидкому економічному розвитку давньоєгипетської держави сприяли значні природні багатства єгипетських долин. Поклади вапняку стимулювали розвиток будівництва кам'яних споруд, а зарості акацій забезпечували необхідною деревиною. Тростина папірус постачала єгиптянам сировину для виготовлення човнів, килимів, матраців, а також слугувала матеріалом для записів. Ніл збагачував раціон єгиптян рибою та водоплавними птахами. Найважливіша корисна копалина енеоліту - мідь зустрічалася у покладах Синайського півострова.

Особливістю давньоєгипетської держави був надзвичайно потужний і розгалужений чиновницький апарат. Рання держава - період його становлення i пошуку оптимальних форм державного управління, економічних та соціальних моделей.

Економічне життя древньоєгипетської держави (як і більшості древніх держав) трималося на т. зв. «вельможному господарстві». Господарем його був вельможа, який займав державну посаду при дворі фараона або в адміністрації нома, а до складу господарства входили його члени сім'ї та слуги. Дослідження поховань вельмож, що за розкішшю іноді не поступаються царським, свідчить про значний достаток i високу економічну самостійність вельмож. Керував вельможним господарством уповноважений господарем управитель, якому, у свою чергу, підпорядковувалися численні прикажчики, писці, обліковці, які слідкували за функціонуванням господарства. Саме господарство могло займати значні території і включати землі по всій території Сгипту. Усе необхідне вироблялося тут же, на місці, натуральним господарством; при цьому робітники забезпечувалися утриманням: продуктами, одежею, знаряддям. Ремісниче виробництво було організованим у спільних багатопрофільних майстернях (палатах майстрів) 3 дрібним розподілом праці (кожен виконував певний етап роботи), де ремісники-чоловіки виготовляли різноманітне знаряддя; також було організовано виробництво харчових продуктів. Жінки працювали у ткацьких майстернях окремо від чоловіків. I самі майстерні, і знаряддя виробництва належали господарю-вельможі, 
йому ж віддавали усі виготовлені ремісниками вироби. Можливо, частина виробів, виготовлена понад встановлену норму, поступала у розпорядження ремісників; вони могли виміняти ії на їжу, одяг, прикраси.

У сільському господарстві, на будівництві іригаційних споруд, при перенесенні вантажів робітників об'єднували у загони; такі загони за необхідності могли перекидатися на інші об'єкти в інші райони. «Вельможне господарство» передавалося у спадок, або ж могло бути придбане в іншого вельможі.

Паралельно з вельможними, у Древньому Єгипті було розвинене «царське господарство». Це було величезне багатопрофільне господарство, що включало як сільськогосподарське (поля, виноградники, садки, пасовиська, млини, пивоварні тощо), так і ремісниче виробництво. Землі царського господарства передавалися вельможам разом 3 посадою i відбиралися разом 3 нею, вельможа не міг повністю розпоряджатися ними. Ті древні тексти, які збереглися до нашого часу, свідчать про чіткий поділ володінь «за істиною» (вельможні) та «за посадою» (царські); хоча посади у Древньому Сгипті зазвичай передавалися у спадок, для цього треба було одержати дозвіл фараона.

Крім царських і вельможних господарств, ймовірно існували й інші форми господарювання (храмові господарства, середні та дрібні приватні господарства), однак, відомості про них до наших часів не збереглися.

Відомо, що у Древньому Сгипті існували ринки для дрібного обміну; барельєфи у гробницях зображують сцени обміну зерна, хліба, риби, овочів на ремісничі вироби і прикраси.

Вже на початку Раннього царства було наявне економічне розщарування, яке поглиблювалося по мірі розвитку Сгипетської держави; свідченням цього є разючі відмінності у спорядженні поховань - від розкішних, наповнених дорогоцінностями і коштовним знаряддям, поховань фараонів і знаті, до практично порожніх могил бідняків.

До часів Раннього царства належать відомості про наявність у єгипетському суспільстві рабів. Відомо, що переважно це були єгиптяни (ймовірно, нащадки підкорених в ході міжусобної боротьби племен), а також полонені, захоплені під час військових дій.

Перші фараони організовували постійні набіги на скотарські племена, що мешкали на території Лівії, захоплюючи худобу й рабів, здійснювали військові походи в Нубію та Синай, а також вели постійну міжусобну боротьбу з Нижнім Сгиптом, що завершилася лише у середині 2600-х років до н.е. остаточним об'єднанням країни.

Період Древнъого царства охоплює більш ніж півтисячолітній час 
правління III - VI династій і характеризується насамперед остаточним об'єднанням країни і формуванням єдиної і потужної Сгипетської держави.

Економічні та технологічні засади періоду Древнього царства не зазнали істотних змін у порівнянні 3 Раннім. Економічно - це те ж поєднання вельможних господарств 3 царським, технологічно - енеоліт, щоправда, з масштабним зростанням кількості вироблених мідних знарядь.

Продовжувало розвиватися землеробство. Основними зерновими культурами залишаються ячмінь і пшениця, вирощували також горох, боби, нут, цибулю, часник, салат-латук, фіги, фініки, смоківницю, виноград, оливки, гранати, яблука. Скотарство забезпечувало м'ясом, шкірами, молоком; єгиптянам були відомі також технології виготовлення масла та кисломолочного сиру. Поряд з бортництвом, з'являються перші спроби домашнього утримання бджіл у глиняних вуликах-глеках. Харчові продукти цінувалися високо, у древніх документах зазначається, що вони є не менш цінними, ніж золото і срібло, одяг та ароматні мастила.

Незважаючи на сприятливі кліматичні умови, періодично траплялися неврожайні роки. У зв'язку 3 цим правителі номів зобов'язувалися створювати запаси продовольства на кілька років, що дозволили б компенсувати нестачу продуктів харчування.

У період Древнього царства остаточно викристалізувалася соціальна структура єгипетського суспільства. Номи, що утворили єгипетську державу, стали адміністративно-господарськими округами, що перебували під жорстким контролем і необмеженою владою фараона.

Фараон стояв на чолі Древньоєгипетської держави (хоча саме слово «фараон» - грецького походження, i з'явилося лише у період Нового царства), і мав необмежену політичну, економічну, військову владу, а також був верховним жерцем. Єгипетська міфологія приписувала фараонам божественне походження; влада фараона обожнювалася, фараону віддавалися божественні почесті. У період Древнього царства верхівка знаті, що здійснювала керівництво державою, складалася виключно 3 родичів фараона.

Першим радником і помічником фараона був верховний сановник (чаті), який керував від імені фараона єгипетським господарством та судовою системою. Військову владу очолював начальник війська, який підпорядковувався безпосередньо фараону.

Паралельно з посиленням державної влади і зміцненням державного апарату, у період Древнього царства зростає роль жерців і формується їхня потужна каста. Особливості погребальних культів Древнього Єгипту вимагали численних жерців для справляння посмертних обрядів; багаті 
єгиптяни витрачали значні суми на оплату таких культів. Найвищі жерці рекрутувалися з верхівки придворної та місцевої адміністрації, вони брали безпосередню участь у керівництві державою в якості радників фараона i номархів - вождів номів.

Адміністративні і розпорядчі функції виконував складний i розгалужений бюрократичний апарат центральних і місцевих чиновників.

Найчисельнішою соціальною групою було залежне населення селяни, ремісники, а також раби. Експлуатація селян та ремісників у вельможних та царських господарствах здійснювалася у формі робочих загонів, які могли оперативно перекидатися у різні місцевості відповідно до господарських потреб. У період Древнього царства формується ринок рабів; їх можна було купувати і продавати.

Удосконалення мідних знарядь і їх виготовлення у значних обсягах дозволило розгорнути масштабне будівництво. Легкий в обробці вапняковий камінь був основним будівельним матеріалом як для будинків, так і для культових споруд, насамперед, пірамід.

У період Древнього царства організовувалися численні військові походи. Їх метою була боротьба зі степовими скотарями, а також «господарські» походи, метою яких було захоплення родовищ корисних копалин (міді, золота, срібла), а також цінних матеріалів (відомі масштабні походи за ліванським кедром, чорним деревом, слоновою кісткою, шкурами левів та леопардів).

Слід зазначити, що у період Древнього царства, поряд з посиленням центральної влади, активізувалися й центробіжні тенденції. Зростання багатства й впливу номархів супроводжувалися прагненням максимальної автономізації від влади фараона. Цей процес супроводжувався кривавими громадянськими конфліктами і завершився близько 2400 р. до н.е. розпадом єдиної єгипетської держави на безліч незалежних номів.

Enоха Середнього царства (2040 - 1783 роки до н.е.) почалася 3 масштабної економічної кризи, викликаної розпадом давньоєгипетської держави на окремі, часто ворожі одне до одного, номи. Розрив зв'язків і конфлікти між номами катастрофічно позначилися на основі економічної могутності єгипетської держави - іригаційній системі землеробства. Складна система зрошувальних споруд, об'єднана у єдиний комплекс, вимагала постійних злагоджених зусиль людей для підтримання їі у робочому стані. У період розпаду держави ця система почала руйнуватися. Канали швидко засмічувалися, а на місцях родючих рівнин знову з'явилися болота. Неминучим результатом занедбання іригаційної системи стали численні випадки голоду, які іноді супроводжувалися людожерством. 
Ослаблення центральної влади супроводжувалося зростанням автономізації номархів. Деякі з них, визнаючи формально владу фараона, фактично наділяли себе атрибутами царської влади: іменували себе синами божеств, вводили власне літочислення, створювали численні армії.

Знову виникла нагальна необхідність у об'єднанні держави. 3 початком правління XII династії починається процес об'єднання розрізнених номів в єдину державу. В результаті стан іригаційної системи значно покращився. Була відновлена система каналів, дамб і гребель. Вдалося знову осушити значні площі боліт, відновити родючість грунтів; в давньоєгипетських хроніках цього часу кількість згадувань про голод значно зменшилася.

Технологічно Середнє царство - період переходу від мідних знарядь до бронзових. Додавання олова до міді дало можливість отримувати набагато більш твердий i довговічний сплав, що позначилося на продуктивності праці.

Удосконалилися й знаряддя праці. Нова форма плугу дозволила полегшити працю землероба, удосконалення зернотерки покращило обробку зерна, а нова конструкція пресу для вичавлювання плодів дала можливість переробляти більшу кількість винограду і фруктів.

Селекція у скотарстві дозволила вивести нові, більш продуктивні породи овець та биків.

У період правління XII династії активно розвивалися зовнішньоекономічні зв'язки Єгипту. Єгиптяни проникають на Синайський півострів і Північну Ефіопію, де видобувалися мідь і золото, а також у Фінікію, звідки вивозилася деревина, та Середземномор'я. Успішні військові походи сприяли зміцненню царської влади і давали можливість покращити економічний стан єгипетської держави.

Середнє царство - період розквіту рабовласництва в Сгипті. Особливо активно праця рабів використовувалася у сільському господарстві. Паралельно відбувалися зміни у положенні залежних селян: вони все частіше залучаються до робіт не лише у царських та вельможних господарствах, а й у приватних, а також відбулись зміни у положенні ремісників: вони об'єднуються у корпорації за фахом, і можуть досягати значного матеріального та суспільного впливу.

В адміністративній і політичній системі суттєвих змін не відбувалося. Номархи, як і раніше, володіли суттєвою владою на місцях, і стали хіба що більш лояльними фараону. Водночас, у центральній владі відбулися певні зміни. Як і раніше, верховний сановник (чаті) уособлював економічну та судову владу, а різноманітні начальники (житниць, скарбниць, 
будівництва, робіт і т.п.) керували відповідними напрямками господарства. Однак, при дворі фараона на важливих державних посадах починають 3'являтися не лише родичі фараона і представники спадкової знаті, а й люди безрідні. Саме ці чиновники, яких фараон наділяв благами й які були зобов' язані йому своєю кар'єрою, складали його основну опору в боротьбі 3 представниками знаті та номархами. Це було вельми актуальним 3 урахуванням того, що міжусобна та міжкланова боротьба не вщухала навіть у період розквіту Середнього царства.

Драматичний фінал Середнього царства був пов'язаний з нашестям східних племен (гіксосів). Понад сторіччя вони панували в Єгипті, однак, створити власну об'єднану державу не змогли. У період XVII династії починається боротьба єгиптян за вигнання завойовників, що знаменує початок останнього періоду існування давньоєгипетської держави - Нового царства.

Нове царство починається з Вигнання гіксоських племен. За доби царствування Тутмоса I (друга половина XVI ст. до н.е.) формується потужна держава, межі якої розширювалися у часи правління наступних фараонів - Тутмоса III, Аменхотепа IV та Рамсеса I, сягнувши четвертого порогу Нілу та північної Сирії. У подальшому, при Рамсесі II, Мернептаху, Рамсесі III Єгипет сам став жертвою набігів сусідніх племен, i, хоча єгиптянам вдалося відбити навалу, держава була ослаблена, що в подальшому відіграло суттєву роль у їі падінні.

На початку XI ст. до н.е. утворилося два єгипетських царства - Нижнє, зі столицею в Танісі, i Верхнє, зі столицею в Фівах. У цей час продовжувалося ослаблення Єгипту, пов'язане з експансією лівійських племен, відділенням Сирії, Фінікії та Палестини та нубійськими завоюваннями.

Фараону Псамметиху I (XXVI династія) вдалося звільнити Єгипет і обєднати єгипетські землі. В подальшому військові походи єгиптян проходили зі змінним успіхом: серед них були як вдалі (іудейський похід, який приніс велику данину), так і невдалі (ієрусалимський та кіренайський походи).

Нове царство продовжувало залишатися епохою бронзи; у цей період з'являлися й залізні знаряддя, однак, залізо було ще дуже дорогим i значного поширення залізні вироби не набули.

Соціально-політична структура давньоєгипетської держави не зазнає суттєвих змін. Процвітає рабовласництво. Раби є бажаною здобиччю під час воєн та міжусобних конфліктів. Активно функціонує ринок рабів; зростаюча потреба у робочій силі в сільському господарстві та ремісництві 
зумовлює постійній ріст цін на рабів, стимулюючи військові походи 3 метою здобуття полонених.

Вільні єгиптяни-землероби (вони називалися царськими людьми) були неоднорідними в соціальному та майновому плані. Серед них були як доволі заможні, які могли мати власних рабів, так і бідні, що мусили працювати день і ніч аби прогодувати себе та свою сім'ю.

Удосконалюються засоби виробництва. У металургії з'являються міхи для горну. У сільському господарстві використовується нова соха, плуг 3 вертикальними рукоятками та перетинками, мотики, молоти для розбивання грудок землі. У ткацькому виробництві використовуються вертикальний станок та гребнеподібні дошки для вичісування льону.

Основне заняття єгиптян - землеробство - зазнало суттєвих змін. В іригаційній справі сталася справжня технічна революція - з'явився шадуф конструкція для підйому води на висоту, що дало можливість доставляти воду на високі поля. Це дозволило займатися садівництвом та городництвом на раніше неродючих землях.

Процвітає садівництво. Поряд 3 вирощуванням вже відомих єгиптянам яблуні, гранату, оливок, з'явилися нові сорти дерев, завезених 3 Азії та Африки - персик, мигдаль, вишня, мирт та інші.

У скотарстві теж відбуваються значні зміни. У цей період також активно розводять віслюків, і зєявляються мули, а також поширюється використання верблюдів. Стара порода овець остаточно витісняється новою, більш продуктивною. Під час нашестя Гіксосів у Єгипті поширилися коні; однак, вони не використовувалися в якості тяглової сили, а вирощувалися виключно у війську, в бойових та виїзних колісницях.

3'являється нова галузь виробництва - виробництво скла. Скляні вироби (різноманітний посуд та прикраси) виготовлялися у спеціалізованих склярських майстернях.

Нове изарство - період пожвавлення торгівлі Древнъого Єгипту. До изього періоду торгівля була розвинена слабко. Натуральне господарство номів повністю забезпечувало потреби в сільськогосподарській та ремісничій продукції. У період Нового царства торгівля залишається переважно міновою, однак, у торгових манускриптах того часу згадується вартість продуктів у золоті та сріблі. При цьому грошовий обіг був практично не розвинений: монет не існувало, а міновим еквівалентом товару виступала певна вагова кількість дорогоцінного металу. Основним грошовим металом було срібло, рідше використовували золото, а згодом - мідь. Торгівці перебували на службі у храмах (ймовірно, збуваючи храмові пожертви) та у приватних осіб. 
Зовнішньоекономічна діяльність полягала у захопленні копалень дорогоцінних металів та збиранні данини з підкорених народів. Під час військових походів єгиптяни здобували золото, срібло, мідь, напівдорогоцінне каміння (бірюза, лазурит), деревину, слонову кістку, а також зерно. Зовнішня торгівля була обмеженою, переважну більшість зовнішнього притоку цінностей забезпечували військові походи.

Падіння Нового царства почалося із перських походів, $i$ завершилося завоюванням Єгипту Олександром Македонським у 332 роиі до н.е.

Податкова система Древнього Єгипту почала формуватися вже в епоху Раннього царства, при I династіі. Вже під час II династії проводиться перша загальнодержавна ревізія - перепис усіх сільськогосподарських запасів Сгипту. В часи III династії щорічно фіксувалася висота води при розливах Нілу - це давало можливість спрогнозувати врожай наступного сезону, і обрахувати податок, який мав надійти у скарбницю.

Записи на камені Палермо (V династія, приблизно 2040 рік до н.е.) повідомляють, що фараон кожні два роки об'їжджав Сгипет, щоб подивитися, як живе його народ, перевірити роботу чиновників, творити правосуддя, а також оцінити фінансовий стан держави і повноту сплати податків.

Вже у другому тисячолітті до н.е. в Древньому Єгипті виник облік доходів і витрат, що фіксував усі дії в державі 3 обігу матеріальних цінностей; це була справжня революція в обліку, що дозволила чітко обліковувати всю господарську діяльність.

Особливістю податкової системи Древнього Сгипту було запровадження нормування податків. Це давало можливість забезпечити безперебійне надходження цінностей у державну скарбницю. В якості об'єктів нормування виступали земельні наділи, зерно, продукти, робітники. Податок сплачували усіма землевласниками - від найдрібніших до найбільших. Від податків звільнялися лише жерці, писці і судді.

В обов' язки податкових чиновників входили розрахунок об'єму податі (він вираховувався відповідно до висоти розливу Нілу), а також власне збір податей. Збір врожаю проходив під постійним контролем чиновників і у повному обсязі надходив на склади під контроль збирача податків. Там він обліковувався, 3 нього вираховувалася подать, а залишки, за наявності, поверталися землевласнику. Ставка податі складала приблизно 30\% від розрахункового обсягу врожаю. При цьому чиновник був матеріально відповідальною особою, i, в разі недоїмки його могли стратити. Це породжувало надмірну завзятість збирачів податків, прикладом якої може слугувати наступний давньоєгипетський запис: «Я чиновник прекрасний для володаря, оскільки поставляю в надлишку зерновий податок, 
поставляю у надлишку численні податі. Мій надлишок зернової податі і інших податей десятикратний...». Зрозуміло, що такий підхід сприяв розоренню землевласників, особливо дрібних.

Іншим об'єктом оподаткування була худоба. Скотарство, особливо розвинене у Нижньому Сгипті, було важливим джерелом надходжень до царської скарбниці.

Перепис худоби в Сгипті проводився кожні два роки. Для цього худобу приганяли у встановлені місця і клеймили. За результатами обліку складалися детальні описи наявної худоби за видами, віком, призначенням тощо.

3 метою стягнення податків з населення періодично проводився його перепис. При переписі зазначалися обсяг земельного наділу, засіяних полів, кількість худоби, а також об'єм податей.

Для забезпечення своєчасного i повного справляння податей в провінщії відряджалися чиновники у супроводі військових загонів. Вони безжально розправлялися з боржниками.

Під час виконання різноманітних робіт здійснювався облік робочої сили за поіменними списками; обліковувалися робочі дні та неявки на роботу з різних причин.

Всі зібрані податі направлялися у царські сховища. Певна частина (близько чверті від зібраного) йшла місцевим храмам в обмін на надання охорони для збирачів податків, решта ставала власністю фараона.

Видаткова частина складалася 3 витрат на оплату ремісникам державних майстерень (ïх забезпечували їжею, одягом, інструментом та олією для змащування тіла, щоб захистити його від палючого сонця), а також на утримання державного апарату i реалізацію проектів 3 будівництва пірамід. Частина податей постійно зберігалася на складах і слугувала продовольчим резервом на випадок неврожайних років.

PhD Oleksandr Belov (Vinnitsya, Ukraine)

\section{ECONOMICS AND LAW IN ANCIENT EGYPT: AN INTRODUCTION TO THE PROBLEM}

The article is devoted to an important theoretical issue of tax psychology - the problem of tax behavior. The author examines the evolution of tax behavior on the example of the slave-owning legal system of the Ta-Kemet State (Ancient Egypt), providing the reader with both well-known historical facts and his own judgments of a professional psychologist. The specifics of the article is its maximum focus on the general reader. It can also be used by students and teachers of the university course "History of Psychology".

Keywords: Slave State, Archaic Era, Tax Behavior, Irrigation, Nomes, Power of the Pharaoh. 
Александр Белов (Винница, Украина)

\section{ЭКОНОМИКА И ПРАВО В ДРЕВНЕМ ЕГИПТЕ: ВВЕДЕНИЕ В ПРОБЛЕМАТИКУ}

Статья посвящена важному теоретическому вопросу налоговой психологии проблеме налогового поведения. Автор рассматривает эволюцию налогового поведения на примере рабовладельческой правовой системы Государства ТаКемет (Древнего Египта), предоставляя на суд читателя как общеизвестные исторические факты, так и собственные суждения профессионального психолога. Специфика статьи состоит её максимальной ориентированности на массового читателя. Также она может быть использована студентами и преподавателями университетского курса «История психологии».

Ключевые слова: рабовладельческое государство, архаическая эпоха, налоговое поведение, ирригация, номы, власть фараона.

Олександр Белов (Вінниця, Україна)

\section{ЕКОНОМІКА І ПРАВО В ДАВНЬОМУ СГИПТІ: ВСТУП ДО ПРОБЛЕМАТИКИ}

Стаття присвячена важливому теоретичному питанню податкової психології проблемі становлення податкової поведінки. Автор розглядає еволюцію податкової поведінки на прикладі рабовласницької правової системи Держави ТаКемет (Давнього Єгипту), передаючи на суд читача як загальновідомі історичні факти, так і власні судження професійного фахівця-психолога. Специфіка статті полягає в ії максимальній орієнтації на масового читача. Також вона може бути використана студентами та викладачами академічного курсу «Історія психології». Ключові слова: рабовласницька держава, архаїчна епоха, податкова поведінка, іригація, номи, влада фараона.

* Белов Олександр Олександрович - кандидат медичних наук, лікар-психіатр, медичний психолог, доцент кафедри медичної психології та психіатрії з курсом післядипломної освіти Вінницького національного медичного університету імені M. I. Пирогова. E-mail: oleksbelov@gmail.com. 